\title{
Determination of Antimicrobial Activity and Chemical Composition of Pimento \& Ginger Essential Oil
}

\author{
Nesrin Şener*1, Sevil Özkinali², Mahmut Gür ${ }^{3}$, Kerim Güney ${ }^{4}$, Osman Emre Özkan ${ }^{3}$, \\ Moustafa Milad Khalifa ${ }^{4}$ \\ ${ }^{1}$ Department of Chemistry, Faculty of Science-Arts, Kastamonu University, Kastamonu, TURKEY \\ ${ }^{2}$ Department of Chemistry, Faculty of Science-Arts, Hitit University, Çorum, TURKEY \\ ${ }^{3}$ Department of Forest Industrial Engineering, Faculty of Forestry, Kastamonu University, Kastamonu, TURKEY \\ ${ }^{4}$ Department of Forest Engineering, Faculty of Forestry, Kastamonu University, Kastamonu, TURKEY
}

\begin{abstract}
The essential oil was obtained from pimento (Pimenta racemosa Mill.) and ginger (Zingiber officinale Rosc.) through hydrodistillation method. The chemical composition of pimento and ginger essential oils were analyzed by GC-MS. It was found that the most abundant components were methyleugenol $(52.33 \%)$ and zingiberene $(16.32 \%)$ in essential oils of pimento and ginger, respectively. The antimicrobial activities of essential oils were investigated against 18 microorganisms with minimum inhibitory concentration (MIC) method. While pimento essential oil behaved strong antimicrobial against all bacteria apart from S. epidermidis, ginger essential oil exhibited poor activity against all bacteria. As a result of this study; it can be suggested that pimento essential oil is a preservative in the medicinal application and food industry.
\end{abstract}

Keywords: Pimento, Ginger, Essential oil, Antimicrobial Activity, Hydrodistillation method, Chemical composition.

\section{INTRODUCTION}

Pimenta racemosa (Miller) J. Moore is a Caribbean tree which grows to a height of about $15 \mathrm{~m}$. It is known to exist in five varieties. Pimenta racemosa is the most widespread among this varieties. ${ }^{1}$ Pimento is commonly used for aromatizing foods. It is used in process of the manufacturing of creams, lotions, detergents, or in the shampoos. It is also used in cosmetics industry. ${ }^{2,3}$ Ginger oil is usually produced from dried ginger by steam distillation method. ${ }^{4}$ The ginger has been used in traditional medicine for treating several sicknesses such as coughs, sinusitis, sore throats, fever and flu. ${ }^{5}$ Ginger extracts, gingerols, and gingerdiol were found to exhibit antiviral, antibacterial and antifungal activities. ${ }^{6-9}$ Also, their synergistic antimicrobial effects ${ }^{4}$ and antihyperlipidemic effects ${ }^{10}$ have been recently reported. The main purpose of the current study is to determine the chemical composition and antimicrobial activities of pimento and ginger essential oils.

\section{MATERIALS AND METHODS \\ Plant Material and Extraction of Essential Oil}

The plant materials obtained from Ankara and identified by the Dr. Kerim Güney. Essential oil was obtained by hydro distillation process using a Clevenger's type apparatus.

\section{GC-MS Analyze}

GC-MS QP 2010 Ultra (Shimadzu) equipped with Rtx-5MS capillary column was used.

\section{Microorganism Strains}

Most of the strains were ATCC, DSMZ and SL type standard strains. Other strains, which have no standard ID information were isolated from food samples and identified
DOI: 10.5530/ijper.51.3s.19 Correspondence: Nesrin Şener, Department of Chemistry, Faculty of Science-Arts, Kastamonu University, Kastamonu, TURKEY Phone no: +90 -3662801972 E-mail: nsener@kastamonu. edu.tr

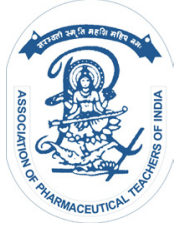

www.ijper.org 
at the Department of Biology, Faculty of Science, and Ankara University.

\section{Antimicrobial Activity}

A broth microdilution MIC test was applied according to the literature. ${ }^{11}$ Two-fold dilutions of the oils were prepared ranging from $100 \mu \mathrm{g} / \mathrm{mL}$ to $0.195 \mu \mathrm{g} / \mathrm{mL}$ by using 96-well micro titration plate. Each well is inoculated with an inoculum prepared as mentioned before. The micro titration plates were incubated at $37^{\circ} \mathrm{C}$ for $24 \mathrm{~h}$ for bacteria strains, where $27{ }^{\circ} \mathrm{C}$ for $48 \mathrm{~h}$ for C. albicans.

\section{RESULTS AND DISCUSSION}

GC-MS analyses revealed that methyleugenol (52.33\%), chavibetol $(19.47 \%)$, caryophyllene $(4.96 \%)$, myrcene (3.72\%), eucalyptol $(2.46 \%)$ and $\alpha$-terpineol $(2.38 \%)$ identified as the components of essential oils; ginger contains zingiberene $(16.32 \%)$, curcumene $(12.42 \%)$, sesquiphellandrene (11.40\%), farnesene (6.51\%), $\beta$-phellandrene (6.01\%), $\beta$-bisabolene (4.23\%), 10- $\beta(\mathrm{H})$ cadina-1(6),4-diene (3.21\%), acoradiene (3.00\%), camphene $(2.92 \%)$ and eucalyptol $(2.48 \%)$ as shown in Table 1.

According to the Table 2, pimento essential oil showed an antimicrobial activity against all microorganisms with a MIC value ranging from $<0.195$ to $100 \mu \mathrm{g} / \mathrm{mL}$. However, ginger essential oil presented antimicrobial activity against some microorganisms with a MIC value ranging between 3.125 and $100 \mu \mathrm{g} / \mathrm{mL}$. The pimento essential oil showed very strong antimicrobial activity against C. albicans, E. faecalis, E. aerogenes, E. durans, E. faecium, E. coli, K. pneumoniae, L. monocytogenes, L. innocua, $P$. aeruginosa, P. fluorescence, S. infantis, S. kentucky, S. typhimurium and $S$. aureus with a MIC value of $<0.195$ $\mu \mathrm{g} / \mathrm{mL}$ for all microorganisms. Also, the pimento essential oil showed strong antimicrobial activity against $B$. subtilis and S. enteritidis with a MIC value of 0.781 and 3.125 $\mu \mathrm{g} / \mathrm{mL}$, respectively.

The pimento essential oil showed very strong antimicrobial activity against 15 different test microorganisms.

\begin{tabular}{|c|c|c|c|c|c|}
\hline Essential Oil & Components & Area $\%$ & Essential Oil & Components & Area \% \\
\hline \multirow{6}{*}{ Pimento } & methyleugenol & 52.33 & \multirow{6}{*}{ Ginger } & zingiberene & 16.32 \\
\hline & chavibetol & 19.47 & & curcumene & 12.42 \\
\hline & caryophyllene & 4.96 & & sesquiphellandrene & 11.40 \\
\hline & myrcene & 3.72 & & farnesene & 6.51 \\
\hline & eucalyptol & 2.46 & & $\beta$-phellandrene & 6.01 \\
\hline & a-terpineol & 2.38 & & $\beta$-bisabolene & 4.23 \\
\hline & & & & $10-\beta(H)$-cadina-1(6),4-diene & 3.21 \\
\hline & & & & acoradiene & 3.00 \\
\hline & & & & camphene & 2.92 \\
\hline & & & & eucalyptol & 2.48 \\
\hline
\end{tabular}

Table 2: MIC values for pimento and ginger $(\mu \mathrm{g} / \mathrm{mL})$

\begin{tabular}{|c|c|c|c|c|c|}
\hline Microorganisms & Pimento & Ginger & Microorganisms & Pimento & Ginger \\
\hline Bacillus subtilis DSMZ 1971 & 0.781 & - & Listeria innocua & $<0.195$ & - \\
\hline Candida albicans DSMZ 1386 & $<0.195$ & 100 & Pseudomonas aeruginosa DSMZ 50071 & $<0.195$ & 100 \\
\hline Enterococcus faecalis ATCC 29212 & $<0.195$ & 100 & Pseudomonas fluorescence $P 1$ & $<0.195$ & 3.125 \\
\hline Enterobacter aerogenes ATCC 13048 & $<0.195$ & - & Salmonella enteritidis ATCC 13075 & 3.125 & - \\
\hline Enterococcus durans & $<0.195$ & - & Salmonella infantis & $<0.195$ & - \\
\hline Enterococcus faecium & $<0.195$ & - & Salmonella kentucky & $<0.195$ & - \\
\hline Escherichia coli ATCC 25922 & $<0.195$ & - & Salmonella typhimurium SL 1344 & $<0.195$ & - \\
\hline Klebsiella pneumoniae & $<0.195$ & - & Staphylococcus aureus ATCC 25923 & $<0.195$ & 100 \\
\hline Listeria monocytogenes & $<0.195$ & 25 & Staphylococcus epidermidis DSMZ 20044 & 100 & 6.25 \\
\hline
\end{tabular}


Also, pimento showed strong antimicrobial activity against two microorganisms, but pimento did not show any antimicrobial activity against $S$. epidermidis. Interestingly, ginger had strong antibacterial activities against P. fluorescence and S. epidermidis. Previous studies revealed that the essential oils of pimento have been found to possess significant antimicrobial and antioxidative activities. ${ }^{12-14}$ Contrary to pimento, the ginger essential oil did not show very strong antimicrobial activity against other test microorganisms. As a result, although the ginger essential oil had a strong antimicrobial activity against two microorganisms, it had moderate and weak antimicrobial activity against one microorganism (L. monocytogenes) and four microorganisms (Candida albicans, E. faecalis, P. aeruginosa, Staphylococcus aureus), respectively.

\section{CONCLUSION}

Finally, it can be suggested that the essential oils of pimento have strong antibacterial activities against different microorganisms of importance to food spoilage and poisoning. The pimento essential oils may find industrial applications as natural preservatives and antimicrobial agents in cosmetics and food industries.

\section{ACKNOWLEDGEMENT}

Authors thank to Kastamonu University.

\section{CONFLICT OF INTEREST}

None

\section{ABBREVIATION USED}

GC-MS: Gas Chromatography Mass Spectometry.

\section{REFERENCES}

1. Tucker AO, Maciarello MJ, Adams RP, Landrum LR, Zanoni TA. Volatile leaf oils of Caribbean Myrtaceae. I. Three varieties of Pimenta racemosa (Miller) J. Moore of the Dominican Republic and the commercial bay oil. Journal of Essential Oil Research. 1991;3(5):323-9.

2. Alitonou GA, Noudogbessi J, Sessou P, Tonouhewa A, Avlessi F, Menut C, et al. Chemical composition and biological activities of essential oils of Pimenta racemosa (Mill) JW Moore from Benin. Int J Biosci. 2012;2:1-12.

3. Opdyke D. Monographs on Fragrance Raw Materials: A Collection of Monographs Originally Appearing in Food and Cosmetics Toxicology: Elsevier; 2013.

4. Khan IA, Abourashed EA. Leung's encyclopedia of common natural ingredients: used in food, drugs and cosmetics: John Wiley \& Sons; 2011.

5. Nampoothiri SV, Venugopalan V, Joy B, Sreekumar M, Menon AN Comparison of essential oil composition of three ginger cultivars from sub Himalayan region. Asian Pacific Journal of Tropical Biomedicine. 2012;2(3):1347-50.

6. Chrubasik S, Pittler MH, Roufogalis BD. Zingiberis rhizoma: A comprehensive review on the ginger effect and efficacy profiles. Phytomedicine. 2005;12(9):684-701.

7. Sharma PK, Singh V, Ali M. Chemical Composition and Antimicrobial Activity of Fresh Rhizome Essential Oil of Zingiber Officinale Roscoe. Pharmacognosy Journal. 2016;8(3):185-90.

8. Sharma P, Singh R. Dichlorvos and lindane induced oxidative stress in rat brain: Protective effects of ginger. Phcog Res 2012;4(1):27-32.

9. Singh N, Gupta S, Rathore V. Comparative Antimicrobial Study of Ethanolic Extract of Leaf and Rhizome of Curcuma longa Linn. Pharmacognosy Journal. 2017;9(2):208-12.

10. Al-Noory AS, Amreen AN, Hymoor S. Antihyperlipidemic effects of ginger extracts in alloxan-induced diabetes and propylthiouracil-induced hypothyroidism in (rats). Phcog Res 2013;5(3):157-61

11. Balouiri M, Sadiki M, Ibnsouda SK. Methods for in vitro evaluating antimicrobial activity: A review. Journal of Pharmaceutical Analysis. 2016;6(2):71-9.

12. Aurore GS, Abaul J, Bourgeois P, Luc J. Antibacterial and antifungal activities of the essential oils of Pimenta racemosa var. racemosa P. Miller (JW Moore) (Myrtaceae). Journal of Essential Oil Research. 1998;10(2):161-4.

13. Burt SA, Reinders RD. Antibacterial activity of selected plant essential oils against Escherichia coli O157: H7. Letters in applied microbiology. 2003;36(3):162-7.

14. Yoshimura M, Amakura Y, Yoshida T. Polyphenolic compounds in clove and pimento and their antioxidative activities. Bio Sci Bio Technol Bio Chem. 2011;75(11):2207-12.

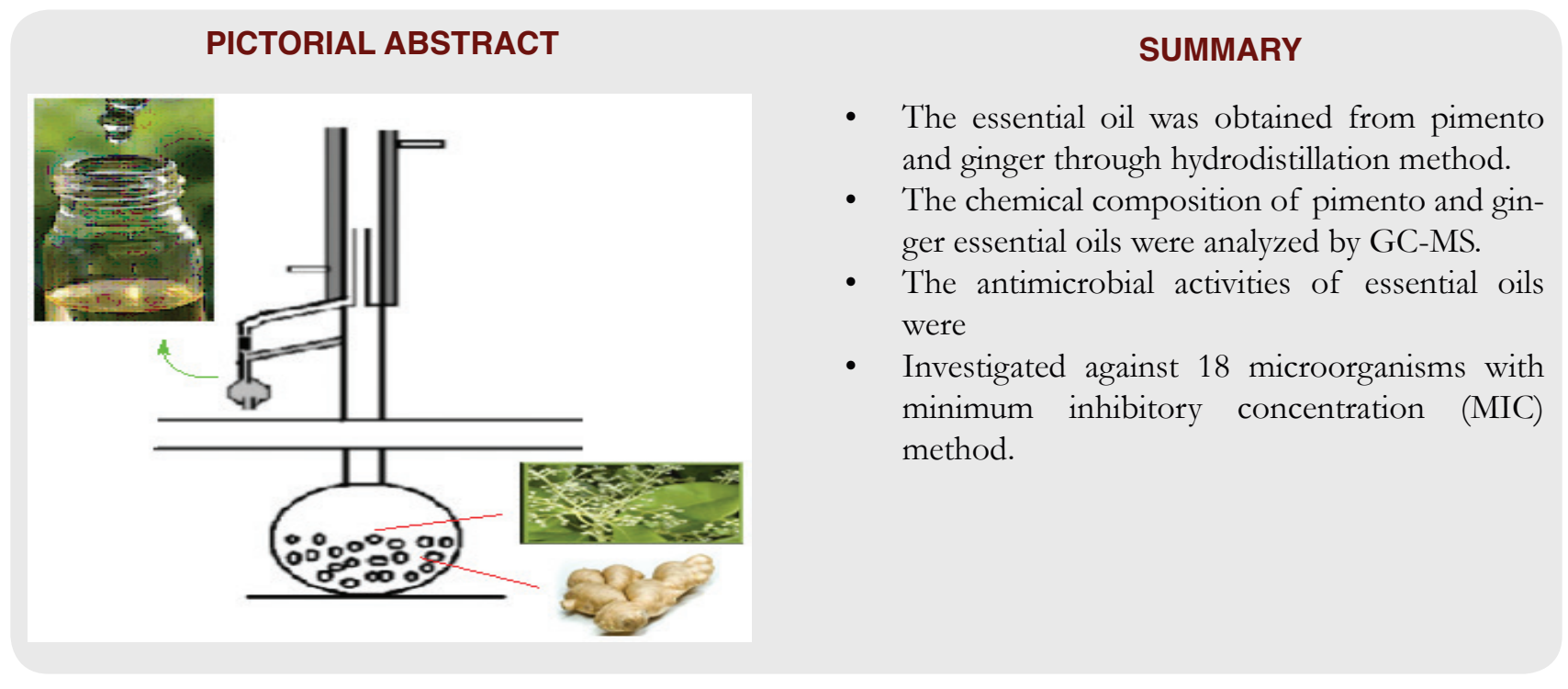




\section{ABOUT AUTHORS}
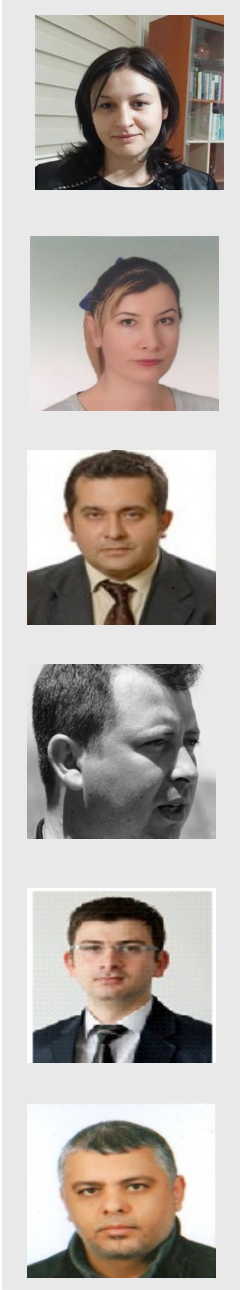

Dr. Nesrin Șener is working as Assistant Professor in Kastamonu University at Chemistry department, Kastamonu. She keeps her interests in the development of synthetic molecules as dyes. She has published a number of publications in different Journals in National and International Repute.

Dr. Sevil Özkınalı is Assistant Proffesor, Department of Chemistry, Faculty of Science and Literature, Hitit University, Çorum, TURKEY. Her areas of research interest include 'Calixarene Chemistry and Spectroscopic Characterization', 'Synthetic Organic Chemistry-and their Antimicrobial-Antioxidant Properties"' and 'Azo dyes, Schiff bases'.

Mahmut GÜR has been working as Assistant Professor in Kastamonu University at Forest Industrial Engineering department, Kastamonu. He is interesting in the development of synthetic molecules. He has published a number of publications in different Journals in National and International Repute.

Kerim GÜNEY has been working as Assistant Professor at Botanic department, Forest Engineering Faculty in Kastamonu University. Kerim Güney has many Publications on flora, vegetation, biodiversity and medical and aromatic plants.

Osman Emre Özkan is working as a research assistant in Forest Industry Engineering Department, Faculty of Forestry in Kastamonu University, TURKEY. Research interests include non-wood forest product and its biological activity.

Mostafa B. Khalifa Milad continues to his Ph.D. at the department of botanic, in Forest Engineering Faculty at Kastamonu University, Faculty of Forestry.

Cite this article: Sener N, Özkinali S, Gür M, Güney K, Özkan OE, Khalifa MM. Determination of Antimicrobial Activity and Chemical Composition of Pimento \& Ginger Essential Oil. Indian J of Pharmaceutical Education and Research. 2017;51(3)Suppl:S230-33. 